\title{
Identification of Molecules from Coffee Silverskin That Suppresses Myostatin Activity and Improves Muscle Mass and Strength in Mice
}

\author{
Jeong Han Kim ${ }^{1,+}{ }^{,}$Jae Hong Kim ${ }^{1,+}$, Jun-Pil Jang ${ }^{2}$, Jae-Hyuk Jang ${ }^{3 \oplus}$, Deuk-Hee Jin ${ }^{1}$, Yong Soo Kim ${ }^{4, *}$ \\ and Hyung-Joo Jin $4, * \mathbb{B}$ \\ 1 Department of Marine Molecular Bioscience, Gangneung-Wonju National University, \\ Gangneung-si 25457, Korea; sinan1708@naver.com (J.H.K.); kej1345@naver.com (J.H.K.); \\ dhjin@gwnu.ac.kr (D.-H.J.) \\ 2 Anticancer Agent Research Center, Korea Research Institute of Bioscience and Biotechnology, \\ Cheongju 28116, Korea; jpjang@kribb.re.kr \\ 3 Natural Medicine Research Center, Korea Research Institute of Bioscience and Biotechnology, \\ Cheongju 28116, Korea; jangjh@kribb.re.kr \\ 4 Department of Human Nutrition, Food and Animal Sciences, University of Hawaii, 1955 East-West Rd., \\ Honolulu, HI 96822, USA \\ * Correspondence: ykim@hawaii.edu (Y.S.K.); hj-jin@gwnu.ac.kr (H.-J.J.); Tel.: +1-808-956-8335 (Y.S.K.); \\ +82-33-640-2349 (H.-J.J.) \\ $+\quad$ These authors contributed equally to this work.
}

\section{check for} updates

Citation: Kim, J.H.; Kim, J.H.; Jang, J.-P.; Jang, J.-H.; Jin, D.-H.; Kim, Y.S.; Jin, H.-J. Identification of Molecules from Coffee Silverskin That

Suppresses Myostatin Activity and Improves Muscle Mass and Strength in Mice. Molecules 2021, 26, 2676. https://doi.org/10.3390/ molecules26092676

Academic Editor:

Seyed Khosrow Tayebati

Received: 16 March 2021

Accepted: 30 April 2021

Published: 3 May 2021

Publisher's Note: MDPI stays neutral with regard to jurisdictional claims in published maps and institutional affiliations.

Copyright: (c) 2021 by the authors. Licensee MDPI, Basel, Switzerland. This article is an open access article distributed under the terms and conditions of the Creative Commons Attribution (CC BY) license (https:// creativecommons.org/licenses/by/ $4.0 /)$.

\begin{abstract}
Coffee has been shown to attenuate sarcopenia, the age-associated muscle atrophy. Myostatin (MSTN), a member of the TGF- $\beta$ growth/differentiation factor superfamily, is a potent negative regulator of skeletal muscle mass, and MSTN-inhibition increases muscle mass or prevents muscle atrophy. This study, thus, investigated the presence of MSTN-inhibitory capacity in coffee extracts. The ethanol-extract of coffee silverskin (CSE) but not other extracts demonstrated anti-MSTN activity in a pGL3-(CAGA) ${ }_{12-}$ luciferase reporter gene assay. CSE also blocked Smad3 phosphorylation induced by MSTN but not by GDF11 or Activin A in Western blot analysis, demonstrating its capacity to block the binding of MSTN to its receptor. Oral administration of CSE significantly increased forelimb muscle mass and grip strength in mice. Using solvent partitioning, solid-phase chromatography, and reverse-phase HPLC, two peaks having MSTN-inhibitory capacity were purified from CSE. The two peaks were identified as $\beta_{N}$-arachinoyl-5-hydroxytryptamide $\left(\mathrm{C}_{20}-5 \mathrm{HT}\right)$ and ${ }^{\beta} \mathrm{N}$-behenoyl-5-hydroxytryptamide $\left(\mathrm{C}_{22}-5 \mathrm{HT}\right)$ using mass spectrometry and NMR analysis. In summary, the results show that CSE has the MSTNinhibitory capacity, and $\mathrm{C}_{20}-5 \mathrm{HT}$ and $\mathrm{C}_{22}-5 \mathrm{HT}$ are active components of CSE-suppressing MSTN activity, suggesting the potential of $\mathrm{CSE}, \mathrm{C}_{20}-5 \mathrm{HT}$, and $\mathrm{C}_{22}-5 \mathrm{HT}$ being developed as agents to combat muscle atrophy and metabolic syndrome.
\end{abstract}

Keywords: coffee silverskin; myostatin inhibition; muscle atrophy; ${ }^{\beta} N$-arachinoyl-5-hydroxytryptamide; $\beta_{N}$-behenoyl-5-hydroxytryptamid

\section{Introduction}

Myostatin (MSTN), also known as growth and differentiation factor-8 (GDF8), is mainly expressed in skeletal muscle and acts as a negative regulator of skeletal muscle growth in animals [1]. During embryonic development, MSTN suppresses muscle cell hyperplasia by inhibiting the proliferation of muscle progenitors and myoblasts $[2,3]$. MSTN also plays an important role in the growth and maintenance of adult skeletal muscle mass [4,5]. The upregulation of MSTN is closely related to muscle atrophy caused by various physiological conditions and illnesses [6-9]. Many studies have shown that suppressing MSTN activity using various approaches, such as administration of MSTNblocking proteins and peptides, delivery of MSTN-blocking genes, and RNAi method 
increases muscle mass in adult animals [10]. Studies have also demonstrated that MSTNblocking is a potential therapeutic strategy to combat muscle wasting occurring in a wide range of serious illness and age-associated sarcopenia in animal models [11,12], as well as in human clinical trials [13-16]. In addition, MSTN suppression improved the insulin sensitivity and whole-body metabolism accompanied by a decrease in fat mass in mice and pigs [17-20], indicating that MSTN plays a role not only in the regulation of muscle mass but, also, in the regulation of fat mass and energy metabolism.

There has been increasing interest in natural compounds from commonly consumed dietary or edible plants as a source of drug candidates for muscle atrophy, and extracts, fractions, or compounds of various dietary plants have demonstrated their potential for the treatment of muscle atrophy [21]. Given that MSTN is a strong negative regulator of skeletal muscle growth and is upregulated in muscle atrophic conditions, examining the MSTN-inhibitory capacities of the extracts and fractions of potential dietary plants appears to be a strategy in searching for natural compounds to treat muscle atrophy. A recent study showed that quercetin, a flavonoid widely distributed in edible plants, has a protective effect on DEX-induced muscle atrophy in a muscle cell culture model [22]. The same study also observed that quercetin enhanced the activation of Akt, a downstream effector of the MSTN signaling pathway, suggesting a potential capacity of quercetin to suppress MSTN activity. Coffee has been reported to attenuate the progression of sarcopenia and to increase the regenerating capacity of injured muscles in aged mice [23]. A decrease in blood proinflammatory cytokines and an increase in Akt activation were observed in coffee-treated mice as compared with control mice. We thus hypothesized that the coffee bin contains compounds capable of MSTN inhibition.

This study was designed to identify compounds that are capable of suppressing the activity of MSTN from coffee bin extract. Our results show that ethanol extracts of coffee silverskin (CSE) suppressed MSTN activity, and its administration to mice increased muscle mass and grip strength along with a decrease in blood fatty acid concentration. ${ }^{\beta} N$-arachinoyl-5-hydroxytryptamide $\left(\mathrm{C}_{20}-5 \mathrm{HT}\right)$ and ${ }^{\beta} N$-behenoyl-5-hydroxytryptamide $\left(\mathrm{C}_{22}-5 \mathrm{HT}\right)$ were identified as the active constituents of CSE suppressing MSTN activity.

\section{Results}

\subsection{Coffee Silverskin Ethanol-Extract (CSE) Suppresses MSTN Activity}

Using the Colombia supremo huila variety, ethanol- and water-extracts of green beans, roasted beans, and silverskin were prepared to determine the presence of anti-MSTN substances in those extracts. The ethanol extract of silverskin (CSE) showed anti-MSTN activity, but other extracts showed little MSTN-inhibitory activity (Figure 1a). Since only CSE showed MSTN-inhibitory activity, the CSE of eight coffee varieties, including Colombia supremo huila, India gangagiri, Ethiopia yirgacheffee, Guatemala SHB huehuetenango, Kenya AA FAQ, Kenya AB TOP, Brazil NY2FC17 / 18 Cerrado, and Ethiopia kochere onacho, were prepared, and their capacities to suppress MSTN activity were examined. The $\mathrm{IC}_{50}$ values of the above eight varieties to suppress MSTN activity were $0.60,2.29,2.78,0.78,1.31$, $0.78,0.62$, and $0.80 \mu \mathrm{g} / \mathrm{mL}$, respectively (Figure $1 \mathrm{~b}$ ). Colombia supremo huila, Guatemala SHB huehuetenango, Kenya AB TOP, Brazil NY2FC17/18 Cerrado, and Ethiopia kochere onacho showed significantly stronger anti-MSTN activity than Kenya AA FAQ. India gangagiri and Ethiopia yirgacheffee showed the lowest MSTN-inhibitory capacity. 
A)

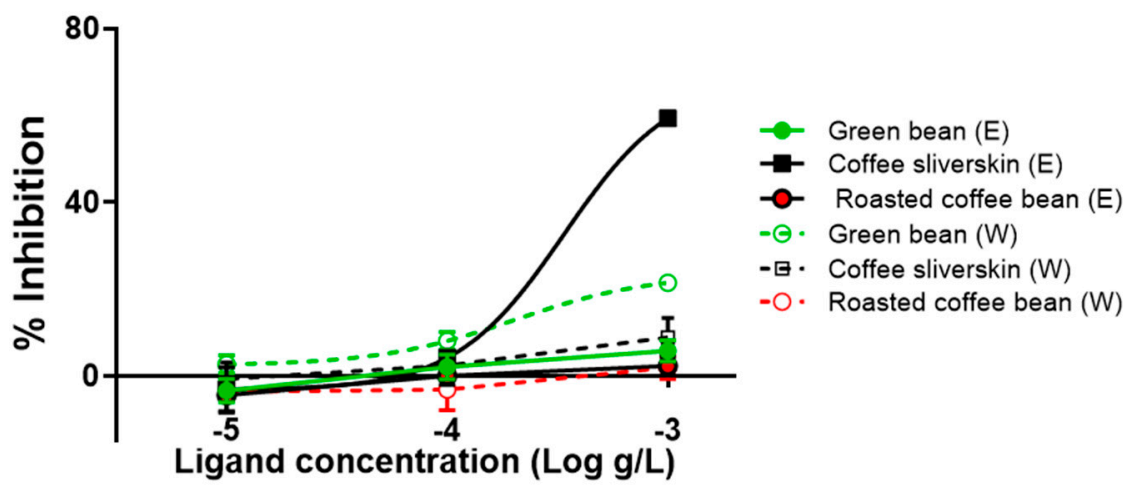

B)

$\mathrm{IC}_{50}$ for $1 \mathrm{nM}$ MSTN inhibition, $\mu \mathrm{g} / \mathrm{mL}$

\begin{tabular}{cccccccc}
\hline 1 & 2 & 3 & 4 & 5 & 6 & 7 & 8 \\
\hline $0.60^{\mathrm{a}}$ & $2.29^{\mathrm{b}}$ & $2.78^{\mathrm{b}}$ & $0.78^{\mathrm{b}}$ & $1.31^{\mathrm{c}}$ & $0.78^{\mathrm{b}}$ & $0.62^{\mathrm{b}}$ & $0.80^{\mathrm{b}}$ \\
\hline
\end{tabular}

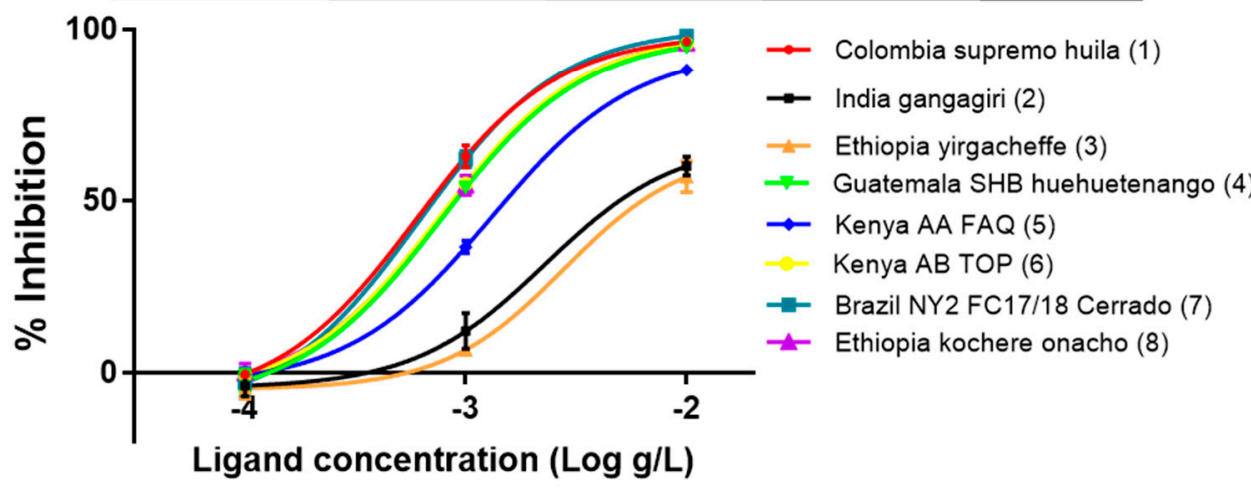

Figure 1. Coffee silverskin ethanol extracts (CSE) inhibit MSTN activity. (A) Anti-MSTN activities of the ethanol and water extracts of Green bean, Roasted coffee bean, and Coffee silverskin of Columbia supremo huila. (B) Anti-MSTN activities of CSE from various coffee varieties. Various concentrations of CSE in combination with 1-nM MSTN were added to the HEK293 cells transformed permanently with (CAGA) 12 -luciferase gene construct, followed by incubation for $24 \mathrm{~h}$ and measurement of the luciferase activity. Percentage of inhibition $=$ (luminescence at $1 \mathrm{nM}$ MSTN-luminescence at each concentration of CSE) $\times 100 /$ (luminescence at $1 \mathrm{nM}$ MSTN-luminescence at $0 \mathrm{nM} \mathrm{MSTN}$. The error bars indicate $\mathrm{SD}(n=3)$. $\mathrm{IC}_{50}$ values not sharing the same superscript are different at $p<0.05$. E, ethanol extract; $W$, water extract.

The capacity of CSE mixture of various varieties to suppress MSTN activity was compared to its capacity to suppress GDF11 and Activin A, the molecules closely related to MSTN, using the luciferase reporter assay. The $\mathrm{IC}_{50}$ for MSTN was $0.79 \mu \mathrm{g} / \mathrm{mL}$, but the $\mathrm{IC}_{50}$ for GDF11 and Activin A were not measurable over the concentration range tested (Figure 2), indicating that CSE's suppression of MSTN is more specific than its suppression of Activin A or GDF11. 


\section{$\mathrm{IC}_{50}$ for $1 \mathrm{nM}$ ligands' inhibition, $\mu \mathrm{g} / \mathrm{mL}$}

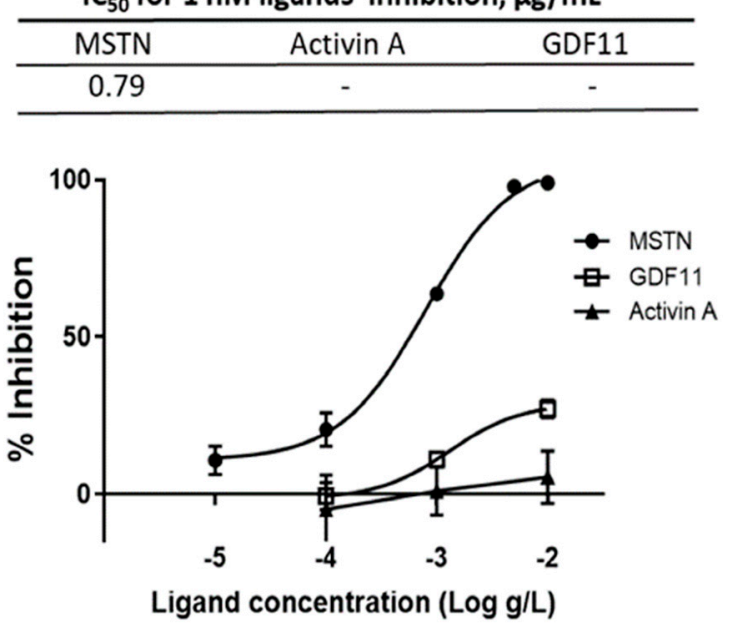

Figure 2. Inhibition of MSTN, Activin A, and GDF11 activities by CSE. Various concentrations of CSE (mixture of various varieties) in combination with $1 \mathrm{nM}$ MSTN, Activin A, or GDF11 were added to the HEK293 cells transformed permanently with (CAGA) 12 -luciferase gene construct, followed by incubation for $24 \mathrm{~h}$ and measurement of the luciferase activity. The error bars indicated SD $(n=3)$. Percentage of inhibition $=$ (luminescence at $1 \mathrm{nM}$ ligands-luminescence at each concentration of CSE) $\times 100$ /(luminescence at $1 \mathrm{nM}$ ligands-luminescence at 0 -nM ligands.

Since CSE demonstrated MSTN inhibitory capacity, we examined whether CSE inhibits MSTN binding to its receptor. MSTN signals through binding predominantly to activin type IIB (ActRIIB) and two type I receptors (ALK4/5) to elicit its biological function [24,25]. The binding of MSTN to ActRIIB recruits and activates type I and type IIB activin receptors, resulting in the phosphorylation of $\mathrm{Smad} 2 / 3$ transcription factors to regulate the expression of downstream target genes, as well as the crosstalk with other signaling pathways [26-28]. GDF11 and Activin A are also known to have signaling pathways similar to MSTN, binding to ActRIIB and activating Smad2/3 pathways $[29,30]$. Thus, the phosphorylation of Smad3 was examined in HepG2 cells treated by MSTN, GDF11, Activin A, with or without CSE. Smad3 was phosphorylated in cells treated by MSTN, and the phosphorylation was suppressed when treated by MSTN with CSE (Figure 3). Both GDF11 and Activin A phosphorylated Smad3 (Figure 3), indicating that MSTN, GDF11, and Activin A have similar signaling pathways. In contrast to MSTN, the phosphorylation of Smad3 induced by GDF11 or Activin A was not inhibited by CSE (Figure 3), demonstrating that CSE inhibits the Smad signaling pathway induced by MSTN but not induced by GDF11 or Activin A. Given that MSTN, GDF-11, and Activin A share the same receptor for their signaling, it appears that the CSE inhibition of Smad3 phosphorylation is via CSE binding to MSTN but not via CSE binding to its receptor, ActRIIB.

\subsection{Oral Administration of CSE Increases the Muscle Mass and Grip Strength but Not Body} Weight and Bone Mass in Mice

Since CSE showed MSTN-inhibitory activity in vitro, we examined in vivo effects of CSE in mice. The oral administration of CSE for 29 days resulted in a significant increase in the forelimb's muscle mass $(2.28 \pm 0.142$ vs. $1.70 \pm 0.102 \mathrm{mg}, p<0.001)$ as compared with the control group, but the hindlimb's muscle mass was not significantly different from the control group ( $2.68 \pm 0.231$ vs. $2.60 \pm 0.101 \mathrm{mg}$ ) (Figure 4c). Additionally, the grip strength of CSE-treated mice was significantly greater as compared with that of the control mice on day $22(0.21 \pm 0.079$ vs. $0.11 \pm 0.068 \mathrm{~N}, p<0.05)$ and on day $29(0.31 \pm 0.161$ vs. $0.09 \pm 0.073 \mathrm{~N}$, $p<0.05$ ) but not on day 8 and 15 (Figure $4 \mathrm{~b}$ ). Body and bone weights were not affected by the CSE administration (Figure 4a,d). 


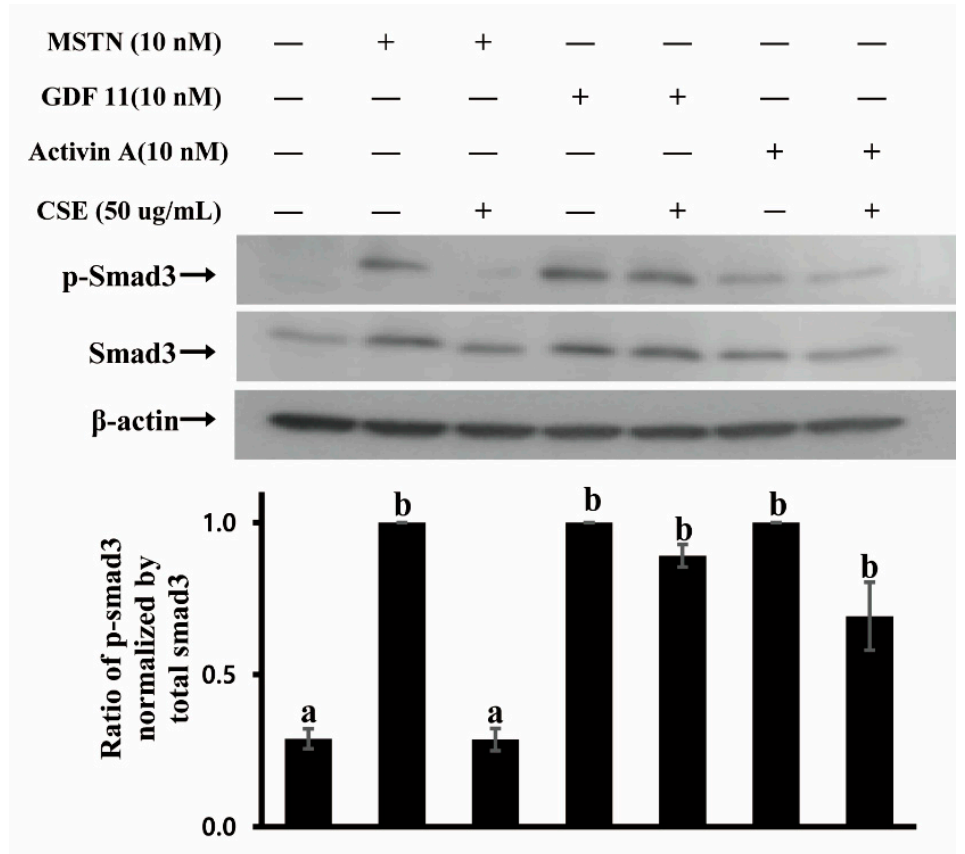

Figure 3. CSE (mixture of various varieties) blocks Smad3 phosphorylation induced by MSTN but not by GDF11 or Activin A in HepG2 cells. Cells were cultured in serum-free DMEM for $4 \mathrm{~h}$, followed by treatment with $10 \mathrm{nM}$ MSTN, $10 \mathrm{nM}$ MSTN plus CSE (50 $\mu \mathrm{g} / \mathrm{mL}), 10 \mathrm{nM}$ GDF11, $10 \mathrm{nM}$ GDF11 plus CSE (50 $\mu \mathrm{g} / \mathrm{mL}), 10 \mathrm{nM}$ Activin A, and $10 \mathrm{nM}$ Activin A plus CSE (50 $\mu \mathrm{g} / \mathrm{mL})$ for $30 \mathrm{~min}$. The blots are representative of three independent assays (Figure S1) and have been sequentially probed with antibodies against phospho-Smad3 (p-Smad3), total Smad3 (Smad3), and $\beta$-actin. Densitometry analyses of the blots were from three independent assays. The relative phosphorylation level of p-Smad3 was normalized by the expression level of total Smad3. The error bars indicate standard deviation $(n=3)$. Different letters are different at $p<0.05$.

(A)
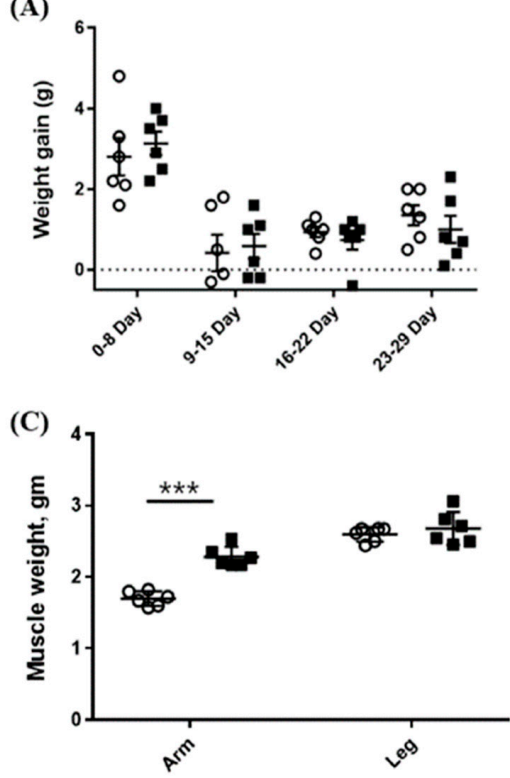

(B)

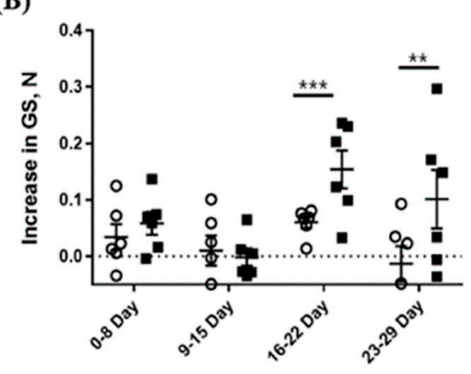

(D)

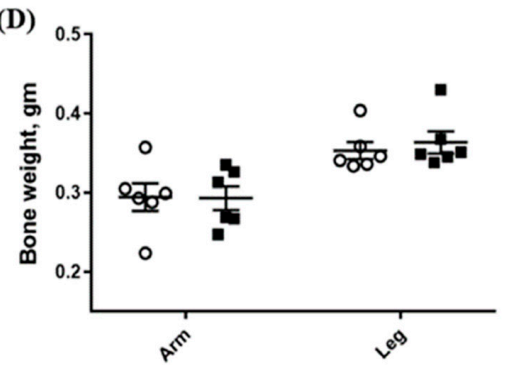

Figure 4. Effects of the oral administration of CSE (mixture of various varieties) on weight gain (A), grip strength (B), muscle weight (C), and bone weight (D). Open circle (o) and closed square ( $\mathbf{\square})$ indicate 0 and $5-\mathrm{mg} / \mathrm{kg}$ body weight oral administration of CSE, respectively. The weights of muscle and bone are combined weights of both right and left sides. Data are means $\pm \operatorname{SEM}(n=6)$. ** $p<0.05 ;{ }^{* * *} p<0.001$. 


\subsection{CSE Administration Decreases the Blood Free Fatty Acid Level}

The free fatty acid level in the blood of CSE-treated mice tended to be lower than that of the control group $(588.6 \pm 127.37 \mu \mathrm{Eq} / \mathrm{L}$ vs. $745.8 \pm 119.59 \mu \mathrm{Eq} / \mathrm{L}, p<0.1)$. However, glucose, total cholesterol, and triglyceride in the blood between the two groups were not significantly different (Table 1 ).

Table 1. Effects of CSE on blood glucose, total cholesterol, triglyceride, and free fatty acid level on day 30.

\begin{tabular}{ccccc}
\hline Group & $\begin{array}{c}\text { Glucose } \\
(\mathbf{m g} / \mathbf{d L})\end{array}$ & $\begin{array}{c}\text { Total Cholesterol } \\
(\mathbf{m g} / \mathbf{d L})\end{array}$ & $\begin{array}{c}\text { Triglyceride } \\
(\mathbf{m g} / \mathbf{d L})\end{array}$ & $\begin{array}{c}\text { Free Fatty Acid } \\
(\boldsymbol{\mu E q} / \mathbf{L})\end{array}$ \\
\hline Control & $286.0 \pm 8.07$ & $127.2 \pm 5.74$ & $129.8 \pm 11.21$ & $745.8 \pm 119.59$ \\
CSE & $291.8 \pm 13.48$ & $132.5 \pm 8.12$ & $129.3 \pm 11.58$ & $588.6 \pm 127.37+$ \\
Relative level (\%) & 102.0 & 104.1 & 99.6 & 78.9 \\
\hline
\end{tabular}

The relative level is expressed as percentages of the values of the CSE group from those in the control group. Values are means \pm SE $(n=6)$. Statistical analyses were performed using Student's $t$-test. $+p<0.1$. CSE; The ethanol extracts of coffee silverskin. The relative level is expressed as percentages of the values of the CSE group from those in the control group. Values are means $\pm \operatorname{SE}(n=6)$. Statistical analyses were performed using Student's $t$-test. $+p<0.1$. CSE; the ethanol extracts of coffee silverskin.

\subsection{Administration of CSE Upregulated the mRNA Expression Level of Ppargc1a and Ucp1 in Mice}

The effect of the oral administration of CSE on the expression of mRNA genes related to energy metabolism was examined. The mRNA expression levels of the Ppargcla $(143 \%, p<0.05)$ and Ucp1 $(508 \%, p<0.01)$ genes were significantly upregulated in the CSE-treated group compared with the control group, while the mRNA expression levels of Fndc5 and Mstn were not significantly different between the two groups (Figure 5).

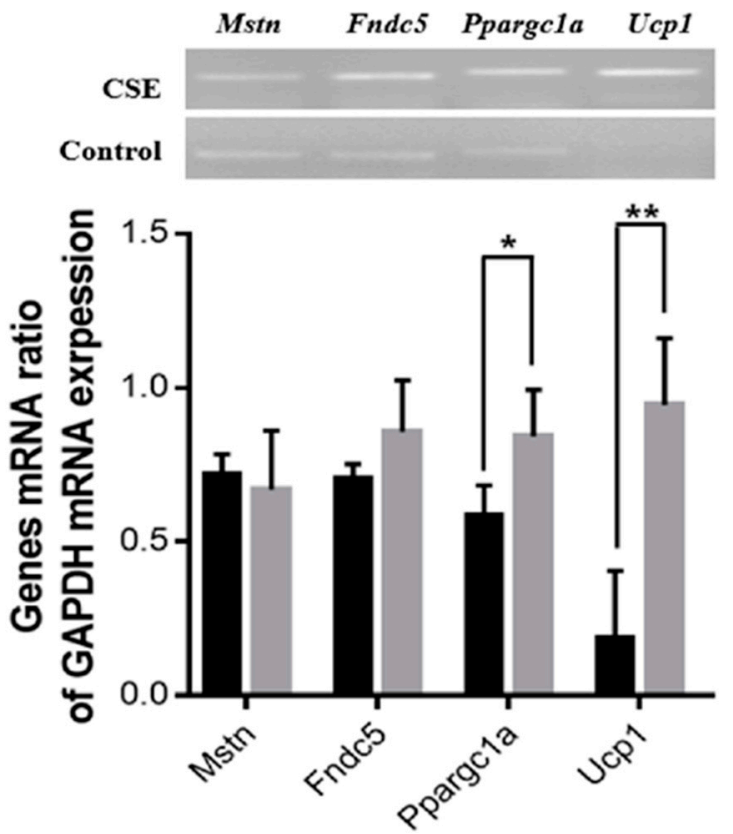

Figure 5. Effects of the oral administration of CSE on the expression of genes related to the metabolism of muscle and fat. The black and gray bars indicate control and CSE-treated groups, respectively. The blots are representative of three independent assays (Figure S2). Data are means \pm SE $(n=3)$. Statistical analyses were performed using Student's $t$-test. ${ }^{*} p<0.05 ;{ }^{* *} p<0.01$.

\subsection{Purification and Structural Identification of Compounds with MSTN-Inhibitory Capacity}

Solvent partitioning results showed that chloroform and hexane fractions inhibited more than $80 \%$ of $1-n M$ MSTN activity while water and $60 \%$ ethanol fractions inhibited less than $20 \%$ of 1-nM MSTN activity in HEK293 cells carrying (CAGA) 12 -luciferase gene 
construct (Figure 6a). Solid-phase extraction chromatography of the chloroform fraction with the C18 Sep-Pak cartridge showed that $80 \%$ and 100\% methanol fractions had MSTNinhibitory capacities (50\% and 70\%, respectively) in HEK293 cells carrying (CAGA) $12^{-}$ luciferase gene construct (Figure 6b).

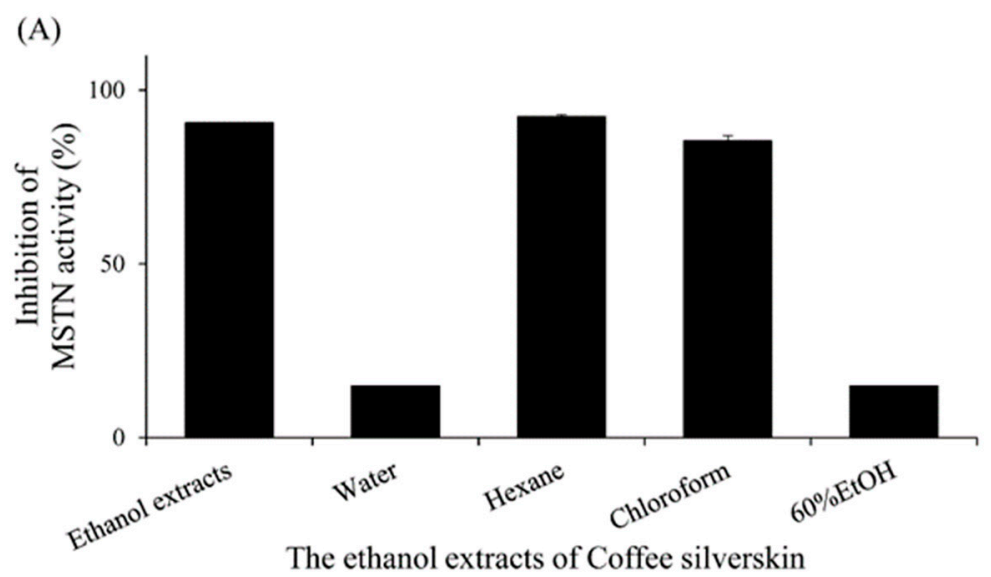

(B)

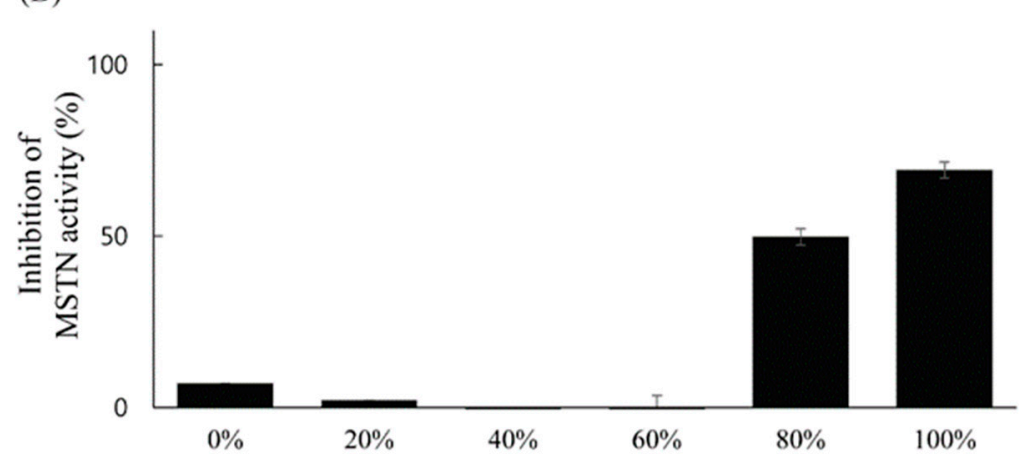

The fractions of C18 Cartridge

Figure 6. Inhibition of MSTN activity by the organic solvent fractions (Water, Hexane, Chloroform, and $60 \%$ Ethanol fractions) of the CSE (A) and by the fractions $(0 \%, 20 \%, 40 \%, 60 \%, 80 \%$, and $100 \%$ methanol) obtained by applying chloroform layer to C18 Sep-Pak cartridge (B). The fractions in combination with 1-nM MSTN were added to the HEK293 cells transformed permanently with (CAGA) 12 -luciferase gene construct, followed by incubation for $24 \mathrm{~h}$ and measurement of the luciferase activity. The error bars indicate the SD $(n=3)$.

Reversed-phase HPLC of the 100\% methanol fraction showed two peaks (Fractions 16 and 19) with MSTN-inhibitory capacity (Figure 7a,b), and the inhibitions were dosedependent (Figure 7c).

In the electrospray ionization mass spectrometry spectrum (ESIMS), peak1 (fraction 15) showed a protonated $[\mathrm{M}+\mathrm{H}]^{+}$ion at $\mathrm{m} / \mathrm{z}$ 471.4. The ${ }^{1} \mathrm{H}$ NMR spectrum of peak1 evidenced the presence of a long alkyl chain due to characteristic signals $\left(\delta_{\mathrm{H}} 0.92\right.$ and 1.30), three aromatic protons $\left(\delta_{\mathrm{H}} 7.16,6.95\right.$, and 6.67$)$, an olefinic proton $\left(\delta_{\mathrm{H}} 7.02\right)$, and two methylene protons $\left(\delta_{\mathrm{H}} 3.46\right.$ and 2.88). The UV spectrum of peak1 was similar to those of 5-hydroxytryptamine with the UV absorption patterns at 280 and $300 \mathrm{~nm}$. Additionally, the spectroscopic data comparison between observed and previously reported data further confirmed that the peak1 is ${ }^{\beta} \mathrm{N}$-arachinoyl-5-hydroxytryptamide $\left(\mathrm{C}_{20}-5-\mathrm{HT}\right)$ (Figure $8 \mathrm{a}$ and Figure S3). The NMR data of the peak2 were similar to those of ${ }^{\beta} \mathrm{N}$-arachinoyl-5-hydroxytryptamide, but the ESIMS showed a molecular ion peak at $\mathrm{m} / \mathrm{z} 499\left([\mathrm{M}]^{+}\right)$, which exceeded that of the latter compound by 28 amu. Additionally, the ${ }^{13} \mathrm{C}$ NMR spectrum of peak2 gave additional methylene signals at $\delta_{C}$ 28.4-29.7, in comparison with that of ${ }^{\beta} \mathrm{N}$-arachinoyl-5-hydroxytryptamide. Thus, 
the structure of the peak2 was elucidated as ${ }^{\beta} \mathrm{N}$-behenoyl-5-hydroxytryptamide $\left(\mathrm{C}_{22}-5-\mathrm{HT}\right)$ (Figure $8 \mathrm{~b}$ and Figure $\mathrm{S} 4$ ).
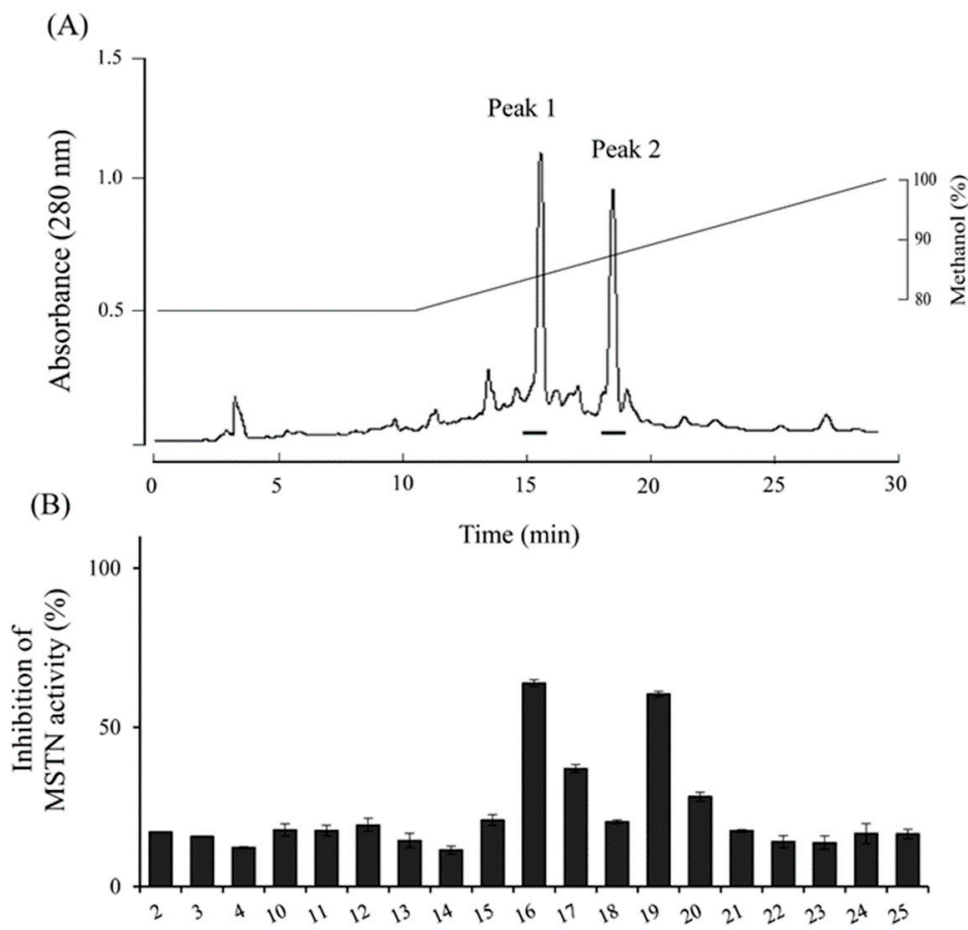

(C) HPLC Fractions

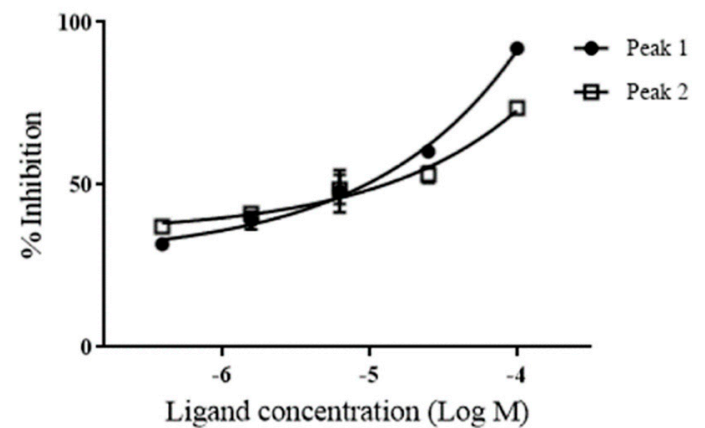

Figure 7. The HPLC profile for the purification of MSTN inhibitors. (A) 100\% methanol fraction of C18 Sep-Pak cartridge was subjected to the reverse-phase HPLC on a Pursuit XRs $5 \mathrm{C}_{18}$ column $(10 \times 250 \mathrm{~mm}$, Agilent technology). It was eluted with an isocratic gradient of $80 \%$ methanol for $10 \mathrm{~min}$, then $100 \%$ methanol for $20 \mathrm{~min}$ at a flow rate of $3.5 \mathrm{~mL} / \mathrm{min}$. The absorbance was monitored at $280 \mathrm{~nm}$. Bars indicate inhibition parts against MSTN activity. (B) Each fraction $(1 \mu \mathrm{g} / \mathrm{mL})$ eluted from HPLC was examined for its inhibitory capacity of 1-nM MSTN. (C) Fraction 15 (peak1) and 19 (peak2) at various concentrations were examined for their inhibitory capacities of 1-nM MSTN. 
(A) Peak $1 ; \mathrm{C}_{20}-5 \mathrm{HT},{ }^{\beta} \mathrm{N}$-arachinoyl-5-hydroxytryptamide<smiles>CCCCCCCCCCCCCCCCCCCC(=O)NCCc1c[nH]c2ccc(O)cc12</smiles>

(B) Peak 2; $\mathrm{C}_{22}-5 \mathrm{HT},{ }^{\beta} N$-behenoyl-5-hydroxytryptamide<smiles>CCCCCCCCCCCCCCCCCCCCCC(=O)NCCc1c[nH]c2ccc(O)cc12</smiles>

Figure 8. The structures of $\mathrm{C}_{20}-5 \mathrm{HT}$ (peak 1) (A) and $\mathrm{C}_{22}-5 \mathrm{HT}$ (peak 2) (B) identified from CSE as MSTN antagonists.

\section{Discussion}

This study first introduces a novel function of the ethanol extract of coffee silverskin (CSE) by showing that CSE suppressed the activity of MSTN, a potent negative regulator of skeletal muscle mass. The MSTN inhibitory capacity of CSE measured by pGL-(CAGA) 12 luciferase reporter gene assay was further confirmed by CSE's blocking of Smad3 phosphorylation, a critical component of the canonical MSTN signaling pathway. MSTN, as a member of the TGF- $\beta$ superfamily, is closely related to Activin A and GDF11 and shares functional redundancy and signaling process via Smad phosphorylation with these ligands, but at the same time, these ligands elicit their specific cellular effects [31]. In this regard, MSTN-inhibitors need to be specific for MSTN inhibition with minimal inhibition of other TGF- $\beta$ superfamily ligands to minimize the nontarget effects in vivo. The current result shows that CSE suppressed MSTN in a pGL-(CAGA) 12 luciferase reporter gene assay, while Activin A and GDF11 were not inhibited by CSE in the concentration range tested. Furthermore, CSE blocked Smad3 phosphorylation induced by MSTN but not by GDF11 or Activin A, indicating that CSE has the potential as a specific MSTN inhibitor.

Studies have shown that the suppression of MSTN activity increases muscle mass in adult animals [10], as well as improves body metabolism and insulin sensitivity $[17,20]$. Since CSE demonstrated MSTN-inhibitory capacity in vitro experiment, we examined the effects of CSE on muscle mass and strength and blood metabolites by daily oral administration of CSE for 29 days in mice. The administration of CSE significantly increased forelimb muscle mass with a concomitant increase in forelimb grip strength. Unexpectedly, hindlimb muscle mass was not affected by the CSE administration. With the current data, the reason for the differential effect cannot be explained, and future studies are needed to confirm and explain the result with detailed mechanistic investigations. Notably, despite the increase in forelimb muscle mass, the body weight was not affected by the administration of CSE. The fat content was not measured in this experiment. Given that MSTN inhibition is known to reduce fat accumulation in mice $[17,18]$, it is likely that the reason for no change in body weight was due to a decrease in fat mass. The free fatty acid concentration in serum was tended to decrease by the administration of CSE, indicating an active utilization of blood free fatty acids by CSE administration. This result is in agreement with other studies that also reported a decrease in blood free fatty acid level by the administration of MSTN-inhibitory compounds in mice fed either a regular [32] or 
high-fat diet [33]. However, the levels of blood glucose and triglyceride were not affected by the administration of CSE in contrast to the results of the above reports [17,31], where decreases in blood glucose and triglyceride were observed by MSTN-inhibitory compound administration. Aligning with the enhanced use of fatty acid by MSTN-inhibition, a study showed that MSTN-inhibition increased the expression of genes regulating lipid metabolism and energy expenditure, such as the Ppargc1a, Ucp1, and Fndc5 genes [17]. Ppargcla upregulates genes involved in the TCA and mitochondrial fatty acid cycles and mitochondrial biogenesis to regulate energy metabolism [34-36]. Both the Ucp-1 and Fndc5 genes, adipose browning markers, have shown to be upregulated by the Ppargc1a [37,38]. Our results also showed that the Ppargc1a and Ucp 1 gene expression was upregulated by CSE administration, while the Fndc5 gene expression was not significantly upregulated, even though the mean was greater $(122 \%, p=0.129)$. These results, the increase in muscle mass and strength, suppressed level of blood fatty acids, and enhanced expression of genes in lipid metabolism, suggest that the CSE administration suppressed MSTN activity in vivo. Furthermore, the results also suggest that the MSTN-inhibiting compound(s) present in CSE is orally active in suppressing MSTN activity in vivo. This study, however, could not thoroughly examine underlying signaling pathways associated with muscle protein metabolism regulated by MSTN, as well as muscle cellularities, such as muscle fiber hypertrophy and hyperplasia, and fiber-type composition, thus future studies need to investigate the underlying mechanisms.

Our results indicated that the potential compound(s) suppressing MSTN activity is mostly present in silverskin and is ethanol-soluble, since ethanol extracts of green beans and roasted beans, as well as the water extract of silverskin, showed little MSTN-inhibitory activity. Caffeine and chlorogenic acid, which are most abundant in green and roasted coffee beans, have various biological activities [34,39]. Given that ethanol- or water-extract of green or roasted coffee beans showed little MSTN-inhibitory activity, it is unlikely that caffeine or chlorogenic acid contributed to the MSTN-inhibitory capacity. Our purification and identification results showed that ${ }^{\beta} N$-arachinoyl-5-hydroxytryptamide $\left(C_{20}-5-\mathrm{HT}\right)$ and $\beta_{N}$-behenoyl-5-hydroxytryptamide $\left(\mathrm{C}_{22}-5-\mathrm{HT}\right)$ isolated from CSE inhibit MSTN activity. The N-alkanoyl-5-hydroxytryptamides, including $\mathrm{C}_{20}-5-\mathrm{HT}$ and $\mathrm{C}_{22}-5-\mathrm{HT}$, are found in the waxy layer of green coffee beans as the major constituent [40,41], as well as in roasted coffee powder [42]. Of note, the ethanol-extract of green coffee bean which was expected to have N-alkanoyl-5-HT did not show MSTN-inhibitory capacity, suggesting that the concentration of $\mathrm{C}_{20}-5-\mathrm{HT}$ and / or $\mathrm{C}_{22}-5-\mathrm{HT}$ in the ethanol extract of the green coffee bean is considerably lower than the CSE.

In summary, results show that ethanol extract of coffee silverskin (CSE) suppresses MSTN activity in vitro, and its administration increased the muscle mass and strength, along with a decrease in the level of blood free fatty acids in mice. $\mathrm{C}_{20}-5 \mathrm{HT}$ and $\mathrm{C}_{22}-5 \mathrm{HT}$ were isolated from CSE as the major compounds contributing to the MSTN inhibition, suggesting the potential of CSE, $\mathrm{C}_{20}-5 \mathrm{HT}$, and $\mathrm{C}_{22}-5 \mathrm{HT}$ being developed as agents to combat muscle atrophy and metabolic syndrome.

\section{Materials and Methods}

\subsection{Coffee Beans}

Green coffee beans, roasted coffee beans, and coffee silverskins of eight different varieties, including Colombia huila supremo, India gangagiri, Ethiopia yirgacheffee, Guatemala SHB huehuetenango, Kenya AA FAQ, Kenya AB TOP, Brazil NY2FC17/18 Cerrado, and Ethiopia kochere onacho, were obtained from the Haeram Coffee Company (Gangneung, Korea). The samples were ground to powder using a coffee grinder following the procedure described previously [43].

\subsection{Preparation of Ethanol and Water Extracts of Samples}

To extract the ethanol-soluble fraction of green coffee beans, coffee silverskins, and roasted coffee beans, $20-\mathrm{g}$ powder samples were mixed with $1 \mathrm{~L}$ of $100 \%$ ethanol and 
incubated at room temperature for $24 \mathrm{~h}$ under a dark condition to reduce light-induced chemical reactions. Two additional extractions were performed and combined. To extract the water-soluble fraction, 20-g powder samples were boiled in $1 \mathrm{~L}$ of water for $20 \mathrm{~min}$. The debris residue was removed by centrifugation $(3000 \times g, 10 \mathrm{~min})$. The weights of ethanol-soluble and water-soluble extracts were measured after complete evaporation of ethanol and water under vacuum at $30^{\circ} \mathrm{C}$ and $50{ }^{\circ} \mathrm{C}$, respectively. After the resolubilization of the ethanol and water extracts, the extracts were filtered through a 0.22 -micron syringe filter before use, as described previously [43].

\section{3. pGL3-(CAGA) 12 -Luciferase Assay}

The luciferase assay was performed in the same manner as in the previous study [44]. Briefly, HEK293 cells stably expressing (CAGA) 12 -luciferase gene construct [45] were seeded on 96-well plates at $2 \times 10^{4}$ cell//well and grown in DMEM containing 10\% FBS, $1 \%$ penicillin/streptomycin, and $1 \%$ geneticin at $37{ }^{\circ} \mathrm{C}$ with $5 \% \mathrm{CO}_{2}$ for $24 \mathrm{~h}$. After incubation, the medium was replaced with $100-\mu \mathrm{L}$ serum-free DMEM, then 1-nM MSTN, Activin A, or growth and differentiation factor 11 (GDF11) (R\&D Systems, Minneapolis, $\mathrm{MN}, \mathrm{USA}$ ), plus various concentrations of the water or ethanol extracts of green bean, coffee silverskin, or roasted coffee bean were added to each well and incubated for $24 \mathrm{~h}$. After incubation, luciferase activity was measured by a microplate luminometer (Berthold, Oak Ridge, TN, USA) using the Bright-Glo luciferase assay system (Promega, Madison, WI, USA). The percentage inhibition of MSTN activity was calculated by the following formula: Percentage of inhibition capacity = (luminescence at 1-nM ligands: MSTN, Activin A, or GDF11)-luminescence at the concentration of each extract) $\times 100 /$ (luminescence at 1-nM ligands: MSTN, Activin A, or GDF11)-luminescence at 0-nM ligands (MSTN, Activin A, or GDF11). The $\mathrm{IC}_{50}$ (ligand concentration inhibiting 50\% of MSTN, GDF11, or Activin A activity) values were estimated by a nonlinear regression model defining a dose-response curve using the Prism6 program (GraphPad, San Diego, CA, USA). The equation for the model was $\mathrm{Y}=$ Bottom $+($ Top-Bottom $) /\left[1+10^{\wedge}(\mathrm{X}\right.$-LogIC 50$\left.)\right]$, where $\mathrm{Y}$ is \% inhibition, Bottom is the lowest value of $\%$ inhibition set at $0 \%$, Top is the highest value of $\%$ inhibition set at $100 \%$, and $X$ is Log ligand concentration. IC $_{50}$ values were analyzed by ANOVA using the same program.

\subsection{Western Blot Analysis}

The effects of the coffee silverskin ethanol extracts (CSE; mixture of various varieties) on MSTN-, GDF11-, and Activin A-induced Smad3 phosphorylation were examined by the Western blot analysis following the procedure previously described [32]. HepG2 cells were seeded in 6-well plates at $2 \times 10^{5}$ cells per well and grown in DMEM containing $10 \%$ FBS and $1 \%$ penicillin/streptomycin at $37{ }^{\circ} \mathrm{C}$ with $5 \% \mathrm{CO}_{2}$ for $24 \mathrm{~h}$. Cells were then switched to serum-free DMEM for $4 \mathrm{~h}$, followed by treatment with 10-nM MSTN (R\&D Systems, Minneapolis, MN, USA), 10-nM MSTN plus CSE (50 $\mathrm{gg} / \mathrm{mL}), 10-n M$ GDF11 (R\&D Systems, Minneapolis, MN, USA), 10-nM GDF11 plus CSE (50 $\mu \mathrm{g} / \mathrm{mL}), 10-\mathrm{nM}$ Activin A (R\&D Systems, Minneapolis, MN, USA), and 10-nM Activin A plus CSE (50 $\mu \mathrm{g} / \mathrm{mL}$ ) for $30 \mathrm{~min}$. Then, cells were lysed in RIPA buffer (20-mM Tris-HCl, pH 7.5, 150-mM NaCl, 1-mM EDTA, 1-mM EGTA, 1\% NP-40, 1\% sodium deoxycholate, 2.5-mM sodium pyrophosphate, 1-mM $\beta$-glycerophosphate, 1-mM Na $3 \mathrm{VO}_{4}$, and 1- $\mu \mathrm{g} / \mathrm{mL}$ leupeptin (Cell Signaling Technology, Danvers, MA, US) containing the protease and phosphatase inhibitor cocktails (Roche, Nutley, NJ, USA). The lysates were sonicated for $15 \mathrm{~s}$ in ice and centrifuged at $14,320 \times g$ for $20 \mathrm{~min}$ at $4{ }^{\circ} \mathrm{C}$. Protein lysates were quantified by the BCA assay (Thermo Scientific, Waltham, MA, USA). Fifty micrograms of protein were separated by $10 \%$ SDS-PAGE and transferred to polyvinylidene fluoride membranes (PVDF; Millipore, Danvers, MA, USA). The membranes were blocked with 5\% BSA in Tris-buffered saline (TBS) containing $0.1 \%$ Tween 20 (TTBS) for $3 \mathrm{~h}$ at room temperature. To assess phosphorylated and total Smad3, the membranes were incubated with primary antibodies specific for target proteins for $3 \mathrm{~h}$ at room temperature. The following primary monoclonal antibodies were purchased from Cell Signaling Technology: 
Smad3 (1:1000) and phospho-Smad3 (1:1000). The membranes were washed with TTBS for $10 \mathrm{~min}$ four times and incubated for $3 \mathrm{~h}$ at room temperature with horseradish peroxidaseconjugated anti-mouse IgG (1:5000). After washing, the reactive bands were detected by the SuperSignal West Femto Maximum Sensitivity Substrate (Thermo Scientific, Waltham, MA, USA) and visualized on Kodak Omat X-ray films. Densitometry analysis of the images obtained from X-ray films was performed using the Image J software (NIH).

\subsection{Animal Experiment}

\subsubsection{Animals}

ICR male mice (6-week-old and weighing 30-35 g) were obtained from Central Lab Animal Inc. (Seoul, Korea). We followed the current regulations for the care and use of laboratory animals, and all the procedures of animal care were approved by the Animal Ethics Committee of Gangneung-Wonju National University, Gangneung, Korea (protocol \#, GWNU-2017-19). The mice were maintained in a room at a constant temperature of $24 \pm 1{ }^{\circ} \mathrm{C}$ under a 12-h light/12-h dark cycle at $65 \%$ humidity. Pellet diet (Purina, Seoul, Korea) and water were provided ad libitum. For a CSE (ethanol extract silverskin) oral administration experiment, mice (6-week-old and weighing 30-35 g) were randomly divided into two groups ( $n=6$ per group). CSE (mixture of various varieties) was diluted in $0.9 \%$ saline solution $(0.75 \mu \mathrm{g} / \mu \mathrm{L})$ and orally administered $(200 \mu \mathrm{L})$ daily for 29 days in the treatment group. Mice in the control group were orally administered with $0.9 \%$ saline solution $(200 \mu \mathrm{L})$. Body weight was measured on days $0,8,15,22$, and 29.

On day 29, after grip strength measurement, mice fasted for $12 \mathrm{~h}$. After fasting, mice were anesthetized with an intramuscular injection of Zoletil 50 (Virbac, Carros, France; $10 \mathrm{mg} / \mathrm{kg}$ ), and blood was collected by cardiac puncture. Serum was prepared by centrifugation at $890 \times g$ for $15 \mathrm{~min}$ at $4^{\circ} \mathrm{C}$ and stored at $-70{ }^{\circ} \mathrm{C}$ until use. After blood collection, the skin was peeled off; then, forelimbs and hindlimbs were disarticulated from scapula to carpus and from ilium to medial malleolus, respectively. The weight of forelimbs and hindlimbs were immediately measured, and the bones were removed immediately from the forelimb and hindlimb and weighed and frozen in liquid nitrogen, then stored at $-70{ }^{\circ} \mathrm{C}$ until use. The muscle weight was calculated by subtracting the bone mass from the weight of the forelimbs and hindlimbs.

\subsubsection{Forelimb Grip Strength Measurement}

Grip strength was measured on day 0 (before the first oral administration), 8, 15, 22, and 29. The tensile force generated by each mouse was measured using a force transducer with a rectangular $4 \times 5 \mathrm{~cm}^{2}$ metal net (Model-RX-10 Aikoh Engineering Co., Osaka, Japan). Briefly, the mouse was slowly pulled by the tail in the opposite direction while its two forelimbs gripped the metal net. The grip strength was recorded in Newtons (N). Each mouse was subjected to a grip test three times, with at least a 1-min rest between trials, and the maximum grip force was recorded as the forelimb grip strength.

\subsubsection{Analysis of Blood Glucose, Cholesterol, Triglyceride, and Free Fatty Acids}

Total cholesterol, triglyceride, and glucose levels in serum were measured by the SD LipidoCare ${ }^{\circledR}$ system-analyzer (SD Biosensor, Seoul, Korea). The level of free fatty acids in serum was measured by colorimetric assay kits (FFA, \#K612-100, Biovision, Milpitas, CA, USA).

\subsubsection{Quantitative Reverse Transcription Polymerase Chain Reaction (qRT-PCR)}

Total RNA was isolated from both side of forelimb muscles for qRT-PCR analysis of Mstn (myostatin), Fndc5 (fibronectin type III domain containing 5), PGC-1a (peroxisome proliferative activated receptor gamma coactivator 1 alpha), and Ucp1 (uncoupling protein 1) genes using TRIzol reagents (Invitrogen, Waltham, MA, USA) following the manufacturer's instructions, and the RNA was used to synthesize cDNA using the PrimeScript ${ }^{\mathrm{TM}}$ 1st strand cDNA synthesis kit (Takara, Shiga, Japan). Briefly, 1- $\mu$ g RNA was added to 
a 9- $\mu \mathrm{L}$ reaction mixture for reverse transcription and placed in a PCR machine at $65{ }^{\circ} \mathrm{C}$ for $5 \mathrm{~min}$. After $5 \mathrm{~min}$, the reaction mixture was adjusted to $20 \mu \mathrm{L}$ by adding $4 \mu \mathrm{L}$ of $5 \mathrm{x}$ PrimeScript buffer, $0.5 \mu \mathrm{L}$ of RNase inhibitor, $1 \mu \mathrm{L}$ of PrimeScript RTase, and $4.5 \mu \mathrm{L}$ of RNase free $\mathrm{dH}_{2} \mathrm{O}$. Thereafter, the reaction mixture was incubated at $42{ }^{\circ} \mathrm{C}$ for $60 \mathrm{~min}$ and finished at $95^{\circ} \mathrm{C}$ for $5 \mathrm{~min}$.

PCR amplification was carried out using the iCycler Thermal Cycler (Bio-Rad, Hercules, CA, USA). The $25-\mu \mathrm{L}$ PCR reaction mixture contained $1 \mu \mathrm{L}$ of cDNA template $(150 \mathrm{ng} / \mu \mathrm{L}) ; 1 \mu \mathrm{L}$ of each primer $(100 \mathrm{pM} / \mu \mathrm{L}) ; 1 \mu \mathrm{L}$ of dNTP mix (consisting of $0.1 \mathrm{mM}$ each of dATP, dCTP, dGTP, and dTTP); $2.5 \mu \mathrm{L}$ of $10 \mathrm{x}$ buffer; $0.5 \mu \mathrm{L}$ of $p f u$ DNA polymerase; and $18 \mu \mathrm{L}$ of distilled water. The cycling parameters consisted of an initial incubation at $94{ }^{\circ} \mathrm{C}$ for $30 \mathrm{sec}, 30$ cycles of 15 -s denaturation at $94{ }^{\circ} \mathrm{C}, 30$-s annealing at $56{ }^{\circ} \mathrm{C}$, and 30-s extension at $72{ }^{\circ} \mathrm{C}$, and a final 3-min extension step at $72{ }^{\circ} \mathrm{C}$ to ensure the complete extension of the amplified products. PCR products were subjected to $1.5 \%$ agarose gel electrophoresis and analyzed by the Vilber Lourmat Imaging System (Vilber Luourmat, Marne La Vallee, France). Glyceraldehyde-3-phosphate dehydrogenase (Gapdh) was used as an internal control to normalize the expression in determining the relative expression of the target genes. The primer sequences used in this study are shown in Table 2.

Table 2. The sequence of primers used for RT-qPCR in this study.

\begin{tabular}{|c|c|c|c|c|}
\hline Gene & Forward Primer $\left(5^{\prime}-3^{\prime}\right)$ & Reverse Primer $\left(5^{\prime}-3^{\prime}\right)$ & $\begin{array}{l}\text { Size } \\
\text { (bp) }\end{array}$ & Accession \\
\hline Mstn & GCTTGACTGCGATGAGCACT & GCACCCACAGCGGTCTACTA & 316 & NM 010834 \\
\hline Fndc5 & TTGATGTGGCAGCAGACTTC & CTTATCCGTCCCTCCTCTCC & 312 & NM_027402 \\
\hline Ppargc1a & ATGTGTCGCCTTCTTGCTCT & GCGGTATTCATCCCTCTTGA & 350 & NM_008904 \\
\hline Ucp1 & СTTCTCAGCCGGAGTTTCAG & TGCCACACCTCCAGTCATTA & 331 & NM_009463 \\
\hline Gapdh & CGTCCCGTAGACAAAATGGT & TCTCCATGGTGGTGAAGACA & 328 & NM_001289726 \\
\hline
\end{tabular}

\subsubsection{Statistical Analysis}

The Student's $t$-test was performed to examine the effect of CSE administration on muscle mass and function, blood metabolites parameters, and gene expressions using the Prism6 program (GraphPad, San Diego, CA, USA).

\subsection{Isolation of Anti-MSTN Inhibitors from CSE}

To isolate the compound(s) having MSTN-inhibitory capacity, the solvent partitioning method was used as illustrated in the following diagram (Figure 9). Dry CSE was mixed with chloroform and water $(v / v=1: 1)$. The mixture solution (chloroform and water) was added to the separating funnel and vigorously shaken 3 to 4 times. The funnel was allowed to stand for $1 \mathrm{~h}$ without disturbance. Once the layers were separated, the layers were carefully collected. This extraction procedure was repeated two more times, and water fractions were pooled and concentrated using a rotary evaporator. The chloroform layer was also concentrated and subjected to solvent partitioning with $90 \%$ ethanol and hexane $(v / v=1: 1)$. The hexane layer and $90 \%$ ethanol layer were separated and concentrated by the same procedure as above. The $90 \%$ ethanol layer was subjected to solvent partitioning with chloroform and $60 \%$ ethanol $(v / v=1: 1)$, and the layers were separated and concentrated. The water, hexane, $60 \%$ ethanol, and chloroform layers were examined for their MSTNinhibitory activities. 


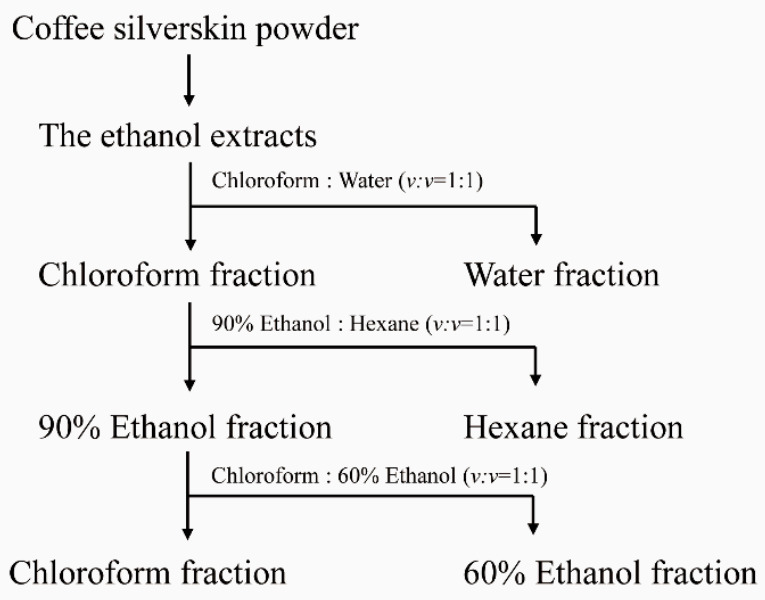

Figure 9. The isolation scheme of CSE using organic solvents.

The chloroform layer, which showed MSTN-inhibitory capacity, was subjected to solid-phase extraction chromatography with a C18 Sep-Pak cartridge (Waters, Milford, MA, USA). The active layer was loaded into the cartridge and eluted with water and methanol at ratios of 100:0, 80:20, 60:40, 40:60, 20:80, and 0:100. The factions were examined for their MSTN-inhibitory capacities. The $100 \%$ methanol fraction, which showed the highest MSTN-inhibitory capacity, was subjected to reverse-phase HPLC (Pursuit XRs 5 and $10 \mu \mathrm{m}$, $10 \times 250 \mathrm{~mm}$, Semipreparative $\mathrm{C}_{18}, 3.5 \mathrm{~mL} / \mathrm{min}$, and UV detection at 202 and $280 \mathrm{~nm}$ ). Elution was performed with an isocratic gradient of $80 \%$ methanol for $10 \mathrm{~min}$, then $100 \%$ methanol for $20 \mathrm{~min}$, and the fractions were examined for their MSTN-inhibitory capacities. For the structural analysis of the separation of compound 1 and compound 2, they were subjected to a 2 nd reverse-phase HPLC (Cosmosil, $10 \mu \mathrm{m}, 10 \times 250 \mathrm{~mm}$, Semipreparative $\mathrm{C}_{18}, 75 \% \mathrm{CH}_{3} \mathrm{CN}, 3 \mathrm{~mL} / \mathrm{min}$, and UV detection at 210 and $280 \mathrm{~nm}$ ).

\subsection{Identification of MSTN Antagonists}

Two distinctive peaks with MSTN-inhibitory capacity were identified using the reverse-phase HPLC separation. To identify the molecular structures of the compounds, LC-MS and NMR experiments were carried out. Liquid chromatography-mass spectrometry (LC-MS) was operated with an LTQ XL linear ion trap (Thermo Scientific, Rockford, IL, USA) equipped with an electrospray ionization (ESI) source that was coupled to a rapid separation LC (RSLC; Ultimate 3000, Thermo Scientific) system (ESI-LC-MS). NMR experiments were operated on the Bruker AVANCE HD 800-MHz NMR spectrometer (Bruker, Berlin, Germany) at the Korea Basic Science Institute (KBSI) in Ochang, Korea. NMR spectra were recorded in $\mathrm{CD}_{3} \mathrm{OD}$ as an internal standard $\left(\delta_{\mathrm{H}} 3.31 / \delta_{\mathrm{C}} 49.0\right)$.

Supplementary Materials: The following are available online. Figure S1: Western blot result, Figure S2: qRT-PCR result, Figure S3: NMR spectrum of SS-P1E, and Figure S4: NMR spectrum of SS-P2E.

Author Contributions: Conceptualization, H.-J.J.; methodology, J.H.K. (Jeong Han Kim), J.H.K. (Jae Hong Kim), J.-P.J., J.-H.J., and H.-J.J.; investigation, J.H.K. (Jeong Han Kim), J.H.K. (Jae Hong Kim), J.-P.J., D.-H.J., and H.-J.J.; resources, Y.S.K. and H.-J.J.; writing-original draft preparation, J.H.K. (Jeong Han Kim), J.H.K. (Jae Hong Kim), Y.S.K., and H.-J.J.; writing-review and editing, all coauthors; supervision, J.-H.J., D.-H.J., Y.S.K., and H.-J.J.; project administration, H.-J.J.; and funding acquisition, H.-J.J. All authors have read and agreed to the published version of the manuscript.

Funding: This research was funded by a grant from the National Research Foundation of Korea (NRF) (No. 2017R1A2B4004152).

Institutional Review Board Statement: We followed the current regulations for the care and use of laboratory animals, and all the procedures of animal care were approved by the Animal Ethics Committee of Gangneung-Wonju National University, Gangneung, Korea (protocol \# GWNU-2017-19). 
Informed Consent Statement: Not applicable.

Data Availability Statement: Not applicable.

Conflicts of Interest: The authors declare no conflict of interest.

Sample Availability: Samples of the compounds are available from the authors.

\section{References}

1. McPherron, A.C.; Lawler, A.M.; Lee, S.-J. Regulation of skeletal muscle mass in mice by a new TGF-p superfamily member. Nat. Cell Biol. 1997, 387, 83-90. [CrossRef]

2. McFarland, D.C.; Velleman, S.G.; Pesall, J.E.; Liu, C. The role of myostatin in chicken (Gallus domesticus) myogenic satellite cell proliferation and differentiation. Gen. Comp. Endocrinol. 2007, 151, 351-357. [CrossRef] [PubMed]

3. Ríos, R.; Carneiro, I.; Arce, V.M.; Devesa, J. Myostatin is an inhibitor of myogenic differentiation. Am. J. Physiol. Physiol. 2002, 282, C993-C999. [CrossRef] [PubMed]

4. Siriett, V.; Salerno, M.S.; Berry, C.; Nicholas, G.; Bower, R.; Kambadur, R.; Sharma, M. Antagonism of Myostatin Enhances Muscle Regeneration During Sarcopenia. Mol. Ther. 2007, 15, 1463-1470. [CrossRef] [PubMed]

5. Whittemore, L.-A.; Song, K.; Li, X.; Aghajanian, J.; Davies, M.; Girgenrath, S.; Hill, J.J.; Jalenak, M.; Kelley, P.; Knight, A.; et al. Inhibition of myostatin in adult mice increases skeletal muscle mass and strength. Biochem. Biophys. Res. Commun. 2003, 300, 965-971. [CrossRef]

6. Han, H.; Mitch, W.E. Targeting the myostatin signaling pathway to treat muscle wasting diseases. Curr. Opin. Support. Palliat. Care 2011, 5, 334-341. [CrossRef] [PubMed]

7. Nishikawa, H.; Enomoto, H.; Ishii, A.; Iwata, Y.; Miyamoto, Y.; Ishii, N.; Yuri, Y.; Hasegawa, K.; Nakano, C.; Nishimura, T.; et al. Elevated serum myostatin level is associated with worse survival in patients with liver cirrhosis. J. Cachex Sarcopenia Muscle 2017, 8, 915-925. [CrossRef]

8. Plant, P.J.; Brooks, D.; Faughnan, M.; Bayley, T.; Bain, J.; Singer, L.; Correa, J.; Pearce, D.; Binnie, M.; Batt, J. Cellular Markers of Muscle Atrophy in Chronic Obstructive Pulmonary Disease. Am. J. Respir. Cell Mol. Biol. 2010, 42, 461-471. [CrossRef]

9. Shyu, K.G.; Lü, M.J.; Wang, B.W.; Sun, H.Y.; Chang, H. Myostatin expression in ventricular myocardium in a rat model of volume-overload heart failure. Eur. J. Clin. Investig. 2006, 36, 713-719. [CrossRef]

10. Chen, P.R.; Lee, K. INVITED REVIEW: Inhibitors of myostatin as methods of enhancing muscle growth and development1. J. Anim. Sci. 2016, 94, 3125-3134. [CrossRef]

11. Lebrasseur, N.K.; Schelhorn, T.M.; Bernardo, B.L.; Cosgrove, P.G.; Loria, P.M.; Brown, T.A. Myostatin Inhibition Enhances the Effects of Exercise on Performance and Metabolic Outcomes in Aged Mice. J. Gerontol. Ser. A Boil. Sci. Med. Sci. 2009, 64, 940-948. [CrossRef]

12. Murphy, K.T.; Ryall, J.G.; Snell, S.M.; Nair, L.; Koopman, R.; Krasney, P.A.; Ibebunjo, C.; Holden, K.S.; Loria, P.M.; Salatto, C.T.; et al. Antibody-Directed Myostatin Inhibition Improves Diaphragm Pathology in Young but not Adult Dystrophic mdx Mice. Am. J. Pathol. 2010, 176, 2425-2434. [CrossRef] [PubMed]

13. Becker, C.; Lord, S.R.; A Studenski, S.; Warden, S.J.; A Fielding, R.; Recknor, C.P.; Hochberg, M.C.; Ferrari, S.L.; Blain, H.; Binder, E.F.; et al. Myostatin antibody (LY2495655) in older weak fallers: A proof-of-concept, randomised, phase 2 trial. Lancet Diabetes Endocrinol. 2015, 3, 948-957. [CrossRef]

14. Lach-Trifilieff, E.; Minetti, G.C.; Sheppard, K.; Ibebunjo, C.; Feige, J.N.; Hartmann, S.; Brachat, S.; Rivet, H.; Koelbing, C.; Morvan, F.; et al. An Antibody Blocking Activin Type II Receptors Induces Strong Skeletal Muscle Hypertrophy and Protects from Atrophy. Mol. Cell. Biol. 2014, 34, 606-618. [CrossRef] [PubMed]

15. Morvan, F.; Rondeau, J.-M.; Zou, C.; Minetti, G.; Scheufler, C.; Scharenberg, M.; Jacobi, C.; Brebbia, P.; Ritter, V.; Toussaint, G.; et al. Blockade of activin type II receptors with a dual anti-ActRIIA/IIB antibody is critical to promote maximal skeletal muscle hypertrophy. Proc. Natl. Acad. Sci.USA 2017, 114, 12448-12453. [CrossRef] [PubMed]

16. Rooks, D.; Praestgaard, J.; Hariry, S.; Laurent, D.; Petricoul, O.; Perry, R.G.; Lach-Trifilieff, E.; Roubenoff, R. Treatment of Sarcopenia with Bimagrumab: Results from a Phase II, Randomized, Controlled, Proof-of-Concept Study. J. Am. Geriatr. Soc. 2017, 65, 1988-1995. [CrossRef] [PubMed]

17. Dong, J.; Dong, Y.; Chen, F.; E Mitch, W.; Zhang, L. Inhibition of myostatin in mice improves insulin sensitivity via irisin-mediated cross talk between muscle and adipose tissues. Int. J. Obes. 2016, 40, 434-442. [CrossRef] [PubMed]

18. Guo, T.; Bond, N.D.; Jou, W.; Gavrilova, O.; Portas, J.; McPherron, A.C. Myostatin Inhibition Prevents Diabetes and Hyperphagia in a Mouse Model of Lipodystrophy. Diabetes 2012, 61, 2414-2423. [CrossRef]

19. Guo, T.; Jou, W.; Chanturiya, T.; Portas, J.; Gavrilova, O.; McPherron, A.C. Myostatin inhibition in muscle, but not adipose tissue, decreases fat mass and improves insulin sensitivity. PLoS ONE 2009, 4, e4937. [CrossRef]

20. Cai, C.; Qian, L.; Jiang, S.; Sun, Y.; Wang, Q.; Ma, D.; Xiao, G.; Li, B.; Xie, S.; Gao, T.; et al. Loss-of-function myostatin mutation increases insulin sensitivity and browning of white fat in Meishan pigs. Oncotarget 2017, 8, 34911-34922. [CrossRef]

21. Shen, S.; Yu, H.; Gan, L.; Ye, Y.; Lin, L. Natural constituents from food sources: Potential therapeutic agents against muscle wasting. Food Funct. 2019, 10, 6967-6986. [CrossRef]

22. Otsuka, Y.; Egawa, K.; Kanzaki, N.; Izumo, T.; Rogi, T.; Shibata, H. Quercetin glycosides prevent dexamethasone-induced muscle atrophy in mice. Biochem. Biophys. Rep. 2019, 18, 100618. [CrossRef] [PubMed] 
23. Guo, Y.; Niu, K.; Okazaki, T.; Wu, H.; Yoshikawa, T.; Ohrui, T.; Furukawa, K.; Ichinose, M.; Yanai, K.; Arai, H.; et al. Coffee treatment prevents the progression of sarcopenia in aged mice in vivo and in vitro. Exp. Gerontol. 2014, 50, 1-8. [CrossRef]

24. Lee, S.-J.; McPherron, A.C. Regulation of myostatin activity and muscle growth. Proc. Natl. Acad. Sci. USA 2001, 98, 9306-9311. [CrossRef]

25. Rebbapragada, A.; Benchabane, H.; Wrana, J.L.; Celeste, A.J.; Attisano, L. Myostatin signals through a transforming growth factor beta-like signaling pathway to block adipogenesis. Mol. Cell. Biol. 2003, 23, 7230-7242. [CrossRef] [PubMed]

26. Bogdanovich, S.; Krag, T.O.B.; Barton, E.R.; Morris, L.D.; Whittemore, L.-A.; Ahima, R.S.; Khurana, T.S. Functional improvement of dystrophic muscle by myostatin blockade. Nat. Cell Biol. 2002, 420, 418-421. [CrossRef] [PubMed]

27. Langley, B.; Thomas, M.; Bishop, A.; Sharma, M.; Gilmour, S.; Kambadur, R. Myostatin Inhibits Myoblast Differentiation by Down-regulating MyoD Expression. J. Biol. Chem. 2002, 277, 49831-49840. [CrossRef]

28. Zhu, X.; Topouzis, S.; Liang, L.-F.; Stotish, R.L. Myostatin signaling through Smad2, Smad3 and Smad4 is regulated by the inhibitory Smad7 by a negative feedback mechanism. Cytokine 2004, 26, 262-272. [CrossRef] [PubMed]

29. Oh, S.P.; Yeo, C.-Y.; Lee, Y.; Schrewe, H.; Whitman, M.; Li, E. Activin type IIA and IIB receptors mediate Gdf11 signaling in axial vertebral patterning. Genes Dev. 2002, 16, 2749-2754. [CrossRef]

30. A Pangas, S.; Woodruff, T.K. Activin Signal Transduction Pathways. Trends Endocrinol. Metab. 2000, 11, 309-314. [CrossRef]

31. Lee, S.-J. Extracellular Regulation of Myostatin: A Molecular Rheostat for Muscle Mass. Immunol. Endocr. Metab. Agents Med. Chem. 2010, 10, 183-194. [CrossRef]

32. Kim, J.H.; Sutikno, L.A.; Lee, S.B.; Jin, D.-H.; Hong, Y.-K.; Kim, Y.S.; Jin, H.-J.; Kim, J.H. Identification of the minimum region of flatfish myostatin propeptide (Pep45-65) for myostatin inhibition and its potential to enhance muscle growth and performance in animals. PLoS ONE 2019, 14, e0215298. [CrossRef] [PubMed]

33. Dong, Y.; Pan, J.S.; Zhang, L. Myostatin Suppression of Akirin1 Mediates Glucocorticoid-Induced Satellite Cell Dysfunction. PLoS ONE 2013, 8, e58554. [CrossRef] [PubMed]

34. Calvo, J.A.; Daniels, T.G.; Wang, X.; Paul, A.; Lin, J.; Spiegelman, B.M.; Stevenson, S.C.; Rangwala, S.M. Muscle-specific expression of PPAR $\gamma$ coactivator- $1 \alpha$ improves exercise performance and increases peak oxygen uptake. J. Appl. Physiol. 2008, 104, 1304-1312. [CrossRef] [PubMed]

35. Hatazawa, Y.; Senoo, N.; Tadaishi, M.; Ogawa, Y.; Ezaki, O.; Kamei, Y.; Miura, S. Metabolomic Analysis of the Skeletal Muscle of Mice Overexpressing PGC-1 $\alpha$. PLoS ONE 2015, 10, e129084. [CrossRef] [PubMed]

36. Huang, T.-Y.; Zheng, D.; Houmard, J.A.; Brault, J.J.; Hickner, R.C.; Cortright, R.N. Overexpression of PGC-1 $\alpha$ increases peroxisomal activity and mitochondrial fatty acid oxidation in human primary myotubes. Am. J. Physiol. Metab. 2017, 312, E253-E263. [CrossRef]

37. Boström, P.A.; Fernández-Real, J.M. Irisin, the metabolic syndrome and follistatin in humans. Nat. Rev. Endocrinol. 2013, 10, 11-12. [CrossRef]

38. Whittle, A. Searching for ways to switch on brown fat: Are we getting warmer? J. Mol. Endocrinol. 2012, 49, R79-R87. [CrossRef]

39. Riedel, A.; Hochkogler, C.M.; Lang, R.; Bytof, G.; Lantz, I.; Hofmann, T.; Somoza, V. N-Methylpyridinium, a degradation product of trigonelline upon coffee roasting, stimulates respiratory activity and promotes glucose utilization in HepG2 cells. Food Funct. 2014, 5, 454-462. [CrossRef]

40. Folstar, P.; Pilnik, W.; de Heus, J.C.; Schols, H.A.; Melger, P.J. Liquid chromatographic analysis of N-alkanoyl-S-hydroxytryptamine (C-5-HT) in green coffee beans. J. Agric. Food Chem. 1979, 27, 12-15. [CrossRef]

41. Folstar, P.; Schols, H.A.; Van Der Plas, H.C.; Pilnik, W.; Landheer, C.A.; Van Veldhuizen, A. New tryptamine derivatives isolated from wax of green coffee beans. J. Agric. Food Chem. 1980, 28, 872-874. [CrossRef] [PubMed]

42. Lang, R.; Bardelmeier, I.; Weiss, C.; Rubach, M.; Somoza, V.; Hofmann, T. Quantitation of 3 N-Alkanoyl-5-hydroxytryptamides in Coffee by Means of LC-MS/MS-SIDA and Assessment of Their Gastric Acid Secretion Potential Using the HGT-1 Cell Assay. J. Agric. Food Chem. 2010, 58, 1593-1602. [CrossRef] [PubMed]

43. Jin, H.-J.; Kim, J.; Sohn, C.H.; DeWreede, R.; Choi, T.; Towers, G.; Hudson, J.; Hong, Y. Inhibition of Taq DNA polymerase by seaweed extracts from British Columbia, Canada and Korea. Environ. Boil. Fishes 1997, 9, 383-388. [CrossRef]

44. Lee, S.B.; Kim, J.H.; Jin, D.-H.; Jin, H.-J.; Kim, Y.S. Myostatin inhibitory region of fish (Paralichthys olivaceus) myostatin-1 propeptide. Comp. Biochem. Physiol. Part B Biochem. Mol. Biol. 2016, 194-195, 65-70. [CrossRef]

45. Cash, J.N.; Angerman, E.B.; Kattamuri, C.; Nolan, K.; Zhao, H.; Sidis, Y.; Keutmann, H.T.; Thompson, T.B. Structure of Myostatin·Follistatin-like 3. J. Biol. Chem. 2012, 287, 1043-1053. [CrossRef] [PubMed] 